\title{
The Effectiveness of Applying Approximate Plane of Brightness Robust to Ambient Light Conditions to View-Based Navigation
}

\author{
Yoshinobu Hagiwara Non-member (Soka University, yhagiwar@soka.ac.jp) \\ Sachio Shimizu Non-member (Panasonic Semiconductor Systems and Technology Co., \\ shimizu.sachio@jp.panasonic.com) \\ Yongwoon Choi Non-member (Soka University, choi@soka.ac.jp) \\ Yuzuru Kubota Non-member (Soka University, yuzuru@soka.ac.jp) \\ Kazuhiro Watanabe Member (Soka University, kazuhiro@soka.ac.jp)
}

Keywords: Robot Vision, View-Based Approach, Lighting Condition, Approximate Plane of Brightness

Recently, the view-based navigation has been proposed as a means to safely control robots in the field of robot vision. This method has been often used for robot navigation from the viewpoint that an image captured by a camera on robots can be simply matched to images memorized beforehand without preparing something in advance such as $3 \mathrm{D}$ models and landmarks in the given environments. However, the method has the problem that fails to navigate robots due to the changes of illumination condition, since it uses a brightness of pixels in the image.

In order to solve the problem, this paper describes an improved view-based navigation on the basis of edge information which is widely known as one of typical image processing method, and however is fraught with a drawback in the noise reduction capability. The edge information used in this work was specially characterized as an approximation plane formed with the brightness of pixels in a given image as shown in Fig. 1. Thus, the improved method has the advantages such as its tough robustness to changeable ambient light conditions and the capability of noise-reduction in the images obtained by recording runs for memorizing a portion of environment.

A series of experiments has been performed in an actual indoor environment with a robot in order to confirm the advantages of this method with verifying that the robot can

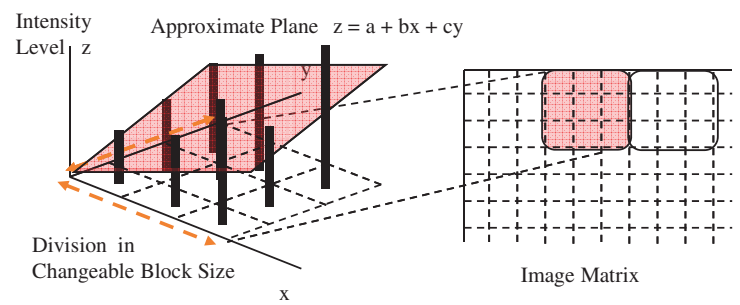

Fig. 1. Approximation plane of brightness recognizes the position memorized by the recording run under the illumination condition of Fig. 2 (a) even in a largely changed condition of (b). Fig. 2 (a) and (b) show the conditions of a little dim by turning on the half of fluorescent lamps and a brighter case in a corridor, respectively.

The experimental results successfully find the improvement whether the robot can correctly identify the positions for six images as shown in Fig. 3 (b) regardless of the changes of ambient light condition, with comparing a pixel-brightness based method in which the positions were apt to be lost in such the ambient condition as shown in Fig. 3(a).

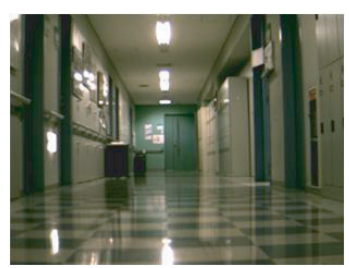

(a) Illumination condition in recording run

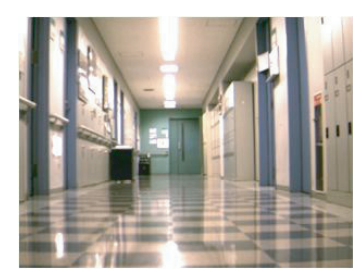

(b) Illumination condition in identification
Fig. 2. Illumination condition in the experiment

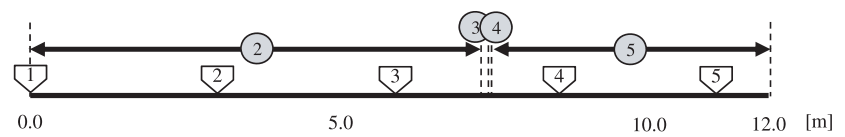

(a) Result of conventional method

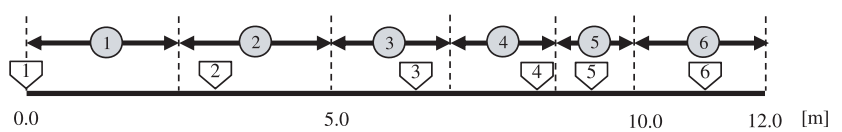

(b) Result of proposal method

No. : Memorized position No. : Identified position

Fig. 3. Experimental results obtained in the environment of Fig. 2 


\title{
照明変化に頑健な輝度近似平面の View Based Navigationへの適用とその効果
}

\author{
非会員 萩原 良信* 非会員 清水 幸夫** \\ 非会員 崔 龍雲* 非会員 久保田 譲* \\ 正 員 渡辺一弘*
}

The Effectiveness of Applying Approximate Plane of Brightness

Robust to Ambient Light Conditions to View-Based Navigation

Yoshinobu Hagiwara*, Non-member, Sachio Shimizu**, Non-member, Yongwoon Choi*, Non-member, Yuzuru Kubota*, Non-member, Kazuhiro Watanabe*, Member

This paper describes a reliable method developed for a view-based navigation which uses approximate planes of image pixel brightness in which edge-based information has been modified with a least-square algorithm. The system developed in this work have shown not only the robustness of this method to ambient lighting conditions due to indoor illumination or daylight from windows, but also the high capability of its noise rejection for images taken in recording runs. This method has been found to be highly tolerated in larger ambient illumination change than the used conventional method where brightness-based pixel values are utilized. Based on this scheme, the experiment has been successfully made in the navigation test even if large ambient lighting condition was given to the robot by means of the change in the number of the luminescent lamps or in the night and the day.

キーワード：ロボットビジョン, ビューベーストアプローチ, 照明条件, 輝度近似平面

Keywords: Robot Vision, View-Based Approach, Lighting Condition, Approximate Plane of Brightness

\section{1. はじめに}

近年, 周囲環境から知的判断を下すための情報の一つと して画像情報が頻繁に用いられている。画像情報は, その 情報量の多さから比較的高度な認識処理に有効で, 様々な 情報が抽出できる点において汎用性も高い。しかし，画像 情報は種々の撮像ノイズや照明の変化などに影響されやす く, 目的の情報を安定して取り出すことが困難になる場合 がある。一般に照明変化の問題に対しては, 正規化係数 ${ }^{(1)}$ や濃度変化 (エッジ) (2)(3) などの照明変化に頑健な画像特 徵を用いる例がある。正規化係数は, 画像全体の絶対值と 各画素の差によって定義される值で, 環境の一様な照明の

\footnotetext{
* 創価大学大学院工学研究科

干 192-8577 東京都八王子市丹木町 1-236

Graduate School of Engineering, Soka University

1-236 Tangi-cho, Hachioji, Tokyo 192-8577

** パナソニックセミコンダクターシステムテクノ(株)

テ 140-0002 東京都品川区東品川 1-3-12

Panasonic Semiconductor Systems and Technology Co., 1-3-12, Higashishinagawa, Shinagawa, Tokyo 140-0002
}

変化に頑健な方法として知られている。一方, 濃度変化は 注目画素とその近傍画素との濃度值の差によって定義され るため, 一様な照明の変化のみならず, 部分的な変化にも 影響されにくい。しかし, 濃度变化の情報は画像の微細な 変化に過度に敏感であるため, 撮像ノイズに影響されやす いという問題がある。

著者らは LCD パネルの輝度の不均一を検出する輝度近 似平面 ${ }^{(4)}$ を提案し, 撮像ノイズの影響を除去しながら緩や かなエッジを検出する方法を提案してきた。最小二乗法を 用いてエッジを定義する輝度近似平面は，言わばエッジの 平均值とも言えるため, 高精細なエッジ画像を構築するに は不向きであるが, 撮像ノイズの影響を軽減して安定した エッジ画像が構築できる(5)。本研究では, 輝度近似平面を 応用して撮像ノイズの影響を軽減しながら環境の照明変化 を許容した画像の比較方法を提案し，これをロボットのナ ビゲーションに適用してその効果を検証する。

画像を用いたロボットナビゲーションの一つとして View Based Navigation ${ }^{(6)}$ が知られている。View Based Navigation は, 予め教示走行によって得られた経路上の記憶 
画像と，現在の位置で得られた画像の照合によってロボッ トの大まかな自己位置を認識して目的地までナビゲーショ ンする方法である。一般に View Based Navigation では, 教示走行において多くの画像を記憶するため, ロボットの 視覚から得られた画像は, 特徴量を抽出して情報量を削減 した“View'として保持される。これまで，周辺画素で平 滑化して View を生成する事で撮像ノイズに対する耐性を 高めた手法 ${ }^{(7)}$ や, 全方位画像の固有值を用いて部分的な景 色の変化に対する耐性を高めた手法 ${ }^{(8)}$ などが提案されて いる。しかしながら，これらの方法は画素の濃度值そのも のを処理して特徵量としているため，空から射し込む太陽 光や蛍光灯による実環境での照明変化に対応していない。 Takeuchi らは，色やエッジの情報に基づいたモデルを作成 し，屋外環境の季節や天候の変化にロバストな方法を提案 している(9)。これらのモデルはいくつかの画像の特徴量を 組み合わせて定義されるため, 環境が变わる度に複数のパ ラメータを設定する手間がある。学習機構を用いてこれを 自動化する研究 (10) も報告されているが, データベースを 構築するために長い期間にわたる学習が必要である。モデ ルを用いた方法は，特定の環境で長期的に使用するには有 効であるが，多様な環境に短期間に適用する場合は手順の 複雑さが問題になる。一方で，複雑なモデルを用いずに照 明変化に対応した方法も提案されている。 Matumotoらは, ステレオカメラから得られる視差画像を用いて屋外の日照 の変化に対応している ${ }^{(7)}$ 。しかし，視差画像は計算コスト が高いため，画像の水平一ラインのみに情報を絞り込むな どの工夫が必要になり，視野の狭さから適用環境が制限さ れる場合がある。このため，計算コストが低く，環境の照 明変化に頑健と考えられる濃度変化を用いる手法は興味深 い。しかし，濃度变化を直接的に View Based Navigation に適用すると，View の照合が視点のずれや撮像ノイズに 影響されやすいという問題がある。

そこで, 濃度変化の情報として輝度近似平面を利用して View を生成し，これを用いる事で屋内環境の照明変化に 頑健な View Based Navigation を実現する。輝度近似平面 は，エッジが近傍画素で平均化されるため，視点のずれや 撮像ノイズを緩和し，Viewの照合時に柔軟性をもたせる 事ができる。本稿では，輝度近似平面を用いた照明変化に 頑健な Viewの生成とその照合の手順，及び本手法を用い て実環境で行ったロボットの走行実験について述べる。実 験では, 移動ロボットに搭載されたカメラの絞りを調整し て擬似的に照明変化を与えた実験から本手法の照明変化に 対する許容範囲を検証する。さらに，実際に太陽光や蛍光 灯によって照明条件が不均一に変化する屋内環境で実験を 行い，実環境における本手法の有効性とその効果を明らか にする。

\section{2. 照明変化に頑健な View の生成}

$\langle\mathbf{2} \cdot \mathbf{1}\rangle$ 濃度変化の情報 一般に濃度変化の情報は, 注 目画素とその近傍における濃度值の変化量を求める事で得

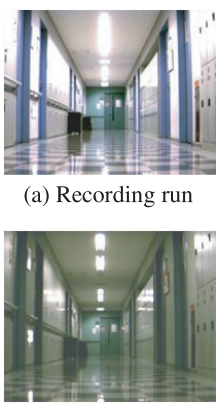

(b) Identification

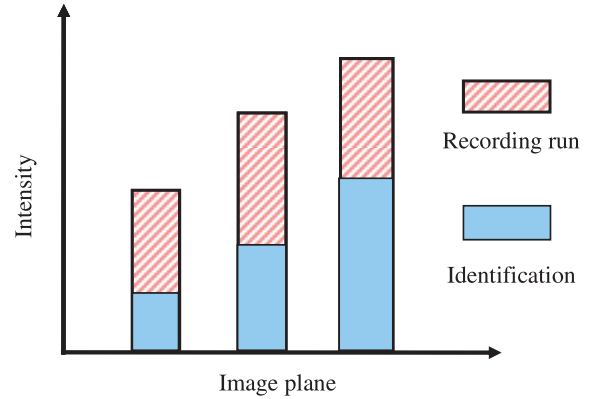

(c) Graph of intensity information between Fig.1 (a) and (b)
図 1 照明変化に対する濃度情報の変化

Fig. 1. Change volumes of intensity information to illumination change

られる画像情報の一つである。この情報は，主に対象の面 領域の境界において濃度值が急激に変化するため, エッジ 検出に用いられている。また画像全体の濃度值が均一に変 化しても影響されないため，テンプレートマッチングや背 景差分において照明変化に頑健な画像特徵として利用され ている(2)(3)。

図 1 は, View Based Navigation の教示走行と自己位置 同定において照明が変化した場合の濃度值の変化を表して いる。図 1(a)，(b) は，それぞれ教示走行時と自己位置同 定時に撮像された画像である。教示走行時に対して自己位 置同定時では, 蛍光灯の点灯数が半分になり, 全体的に画 像が暗くなっている。図 1(c) は図 1(a), (b) の任意の領域 における各画素の濃度值を概念的に表したグラフである。 グラフの斜線と実線の縦棒はそれぞれ教示走行時と自己位 置同定時の濃度值である。実線の自己位置同定は, 斜線の 教示走行に比べて点灯している蛍光灯が半分になっている ため, 画像の濃度值は全体的に低くなる。同じ地点で撮像 された画像であっても, 照明の変化によって濃度值には大 きな変化が生じる。このため, 濃度值を直接的に用いた手 法では教示走行時と自己位置同定時で照明が変化した場合, 正常に照合する事が困難であった。一方，図 1(c) の教示走 行時と自己位置同定時における 3 つの画素の濃度值の傾き に着目すると, 照明が変化した場合においても 3 つの画素 の濃度值の傾きには変化が無い事がわかる。本研究では, この濃度值の傾きを濃度変化と定義し, 濃度変化の情報に 基づいた View を用いる事で, 照明の変化に頑健な View Based Navigation を提案する。

$\langle 2 \cdot 2\rangle \quad$ 濃度变化の検出方法＼cjkstart画像から濃度変化の情 報を得るための手法としては, 画像微分法がよく知られて いる。画像微分法は, 空間フィルタと画像との掛け合わせ によって濃度変化を検出する手法で, 適用する環境や用途 に応じて様々な空間フィルタが提案されている。一般に画 像微分法は隣接画素との差分に基づてて処理するため, 計 算コストが低い利点がある。しかし，一方で局所的に濃度 值が変化する撮像ノイズに影響を受けやすい問題もある。 特にロボットに設置されるカメラは, 設置スペースや電力 
の問題から高性能なカメラを用いる事が難しく, 撮像画像 がノイズを多く含む事が考えられる。

そこで本研究では, 最小二乗法によって濃度変化を定義 する輝度近似平面 (4) をView Based Navigationに適用す る事でこの問題を解決する。輝度近似平面は，二次元に拡 張した最小二乗法によって近傍画素の濃度值を平面式に近 似し，この平面の傾きから濃度変化を定義する方法である。 この方法は, 画像微分法に比べてパラメータが少ないため に高精度な濃度変化の検出には不向きであるが，一つのパ ラメータの変更で，撮像ノイズに対する耐性を簡便に調整 する事ができる(5)。View Based Navigation に最適な画像 処理パラメータは, 適用環境やロボットに搭載されたカメ ラの性能に応じて変化するため, 簡便なパラメー夕設定で 環境の変化に対応できる輝度近似平面はこのような目的に 適している。

〈2·3〉View の生成輝度近似平面では, 図 $2(\mathrm{a})$ の ように画像を任意のサイズのブロックに分割する。このと きのブロックサイズは, 輝度近似平面における最小二乗法 の近似区間であり，一つのパラメータによって簡便に調整 する事ができる。分割されたブロックでは，各画素の濃度 值を最小二乗法で近似した平面 $z=a+b x+c y$ が求まる。 さらに, この平面に揸りる濃度変化の強度 (Strength) と方 向 (Direction) の情報を以下の式から定義できる。

$$
\begin{aligned}
& \text { Strength }=\sqrt{b^{2}+c^{2}} . \\
& \text { Direction }=\tan ^{-1} \frac{c}{b} \ldots
\end{aligned}
$$

(2) 式の方向情報は, 明瞭な輪郭が無い物体の面などでは 安定しない。また，ロボットに搭載されたカメラでは，走 行中の振動や視点のずれによって輪郭部でも方向成分が不 安定になるため, 本手法では強度の情報のみを用いて画像 を照合する。図 2(b) の撮像画像に対してブロックサイズ $10 \times 10$ (pixel) の輝度近似平面を適用して生成された画像

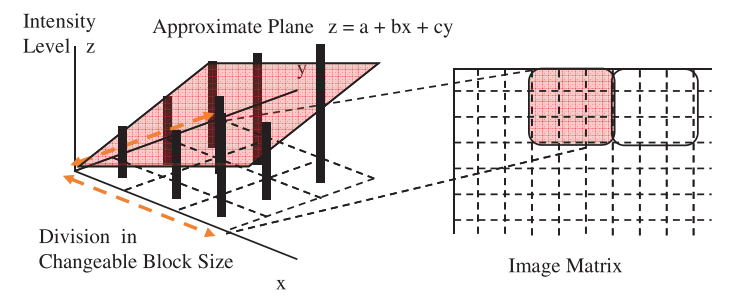

(a) Brightness Approximate Plane Method

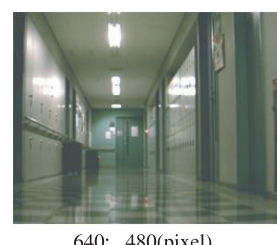

b) Captured image
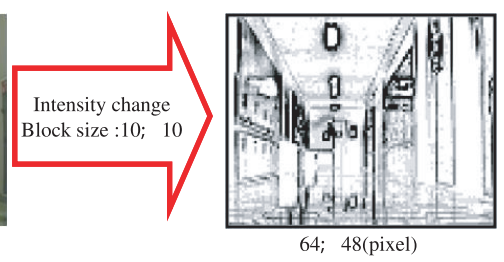

(c) Generated View
図 2 照明変化にロバストなビューの生成

Fig. 2. Generation of a robust view in illumination changes
（View）が図 2(c) である。生成されたView は, 濃度変化 を見やすくするため，8階調の画像で示している。同図で の白は濃度変化の傾きが小さいブロック，黒は濃度変化の 傾きが大きいブロックを表している。エッジにおいて強い 濃度変化の傾きが得られている事がわかる。このとき, 生 成された画像（View）の解像度は元画像をブロックサイズ で割った解像度になっており，ブロックサイズを調整する 事で記憶画像の情報量や撮像ノイズ，視点ずれへの耐性が 調整できる。256 階調グレースケールのVGA 画像を $10 \times$ 10(pixel) のブロックで処理した場合, 生成画像の解像度は 1/100, 強度に float 型を用いた場合は画素あたり 4 倍にな るので, 情報量は $1 / 25$ になる。ブロックサイズは大きくす ると平滑化作用によって撮像ノイズや視点ずれへの耐性が 高くなるが, 画像の変化に鈍感になるため, ナビゲーショ ンの要求に応じて適切に設定する必要がある。

\section{3. ナビゲーションの手順と View の照合}

〈3・1〉 教示走行 View Based Navigation における 教示走行の手順を図 3 に示す。教示走行では, ロボットを マニュアルで操作し, 走行する経路上の画像 (View) を記憶 させる。この時, カメラから取得された画像を毎フレーム 記憶すると, 記憶された画像間での変化が少ないため, 自 己位置同定において現在の View と類似するView が複数 見つかり，自己位置を一意に同定する事が困難になる。そ こで，記憶するViewは，図 3 の上段に示すように前回記 憶したView との相関值を計算し, 一定の閾值以下に画像 が変化した場合に次の View を記憶する事とした。グラフ の縦軸はView の相関值, 横軸は画像のフレーム数で, グラ フ下部の点線はView を記憶する相関值の閾值である。ロ ボットが矢印の方向に移動した場合の 1st viewの相関值の 推移 $\mathrm{c} 1$ は, ロボットの移動に伴って低下し, 閾值を下回っ た段階で, 次のViewを記憶する。この処理を繰り返し行 う事で, 走行する経路上の View を予めロボットに記憶さ せる。

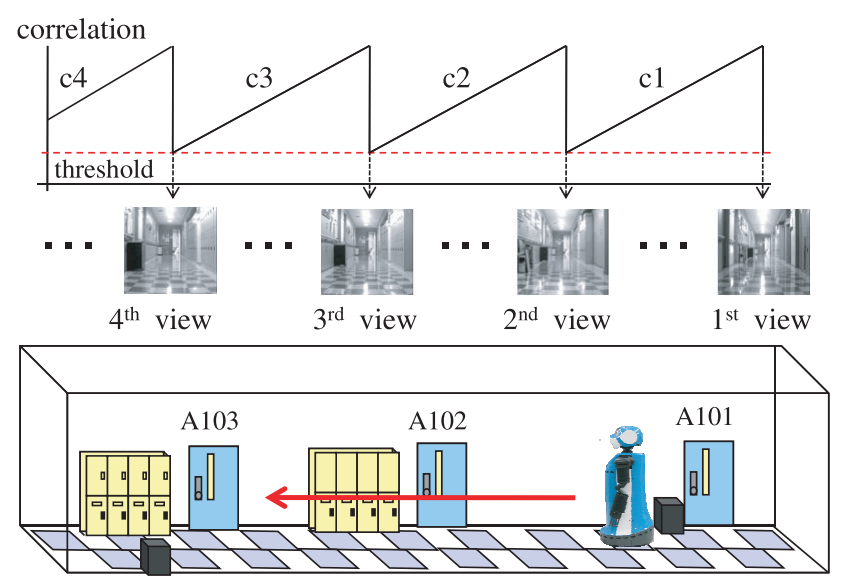

図 3 教示走行におけるビューの記憶

Fig. 3. Memorized views in recording run 


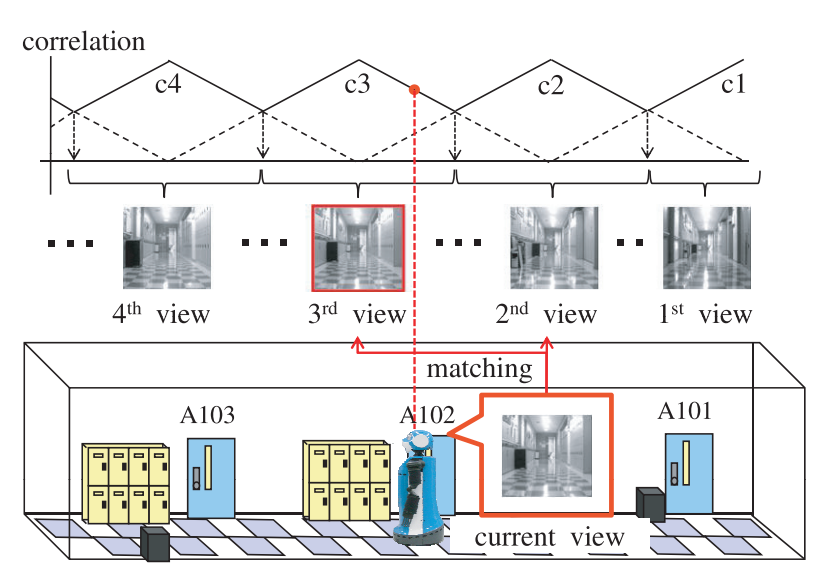

図 4 自己位置同定におけるビューの照合

Fig. 4. Matching views in identification

$\langle\mathbf{3} \cdot \mathbf{2}\rangle$ 自己位置同定 図 4 は View Based Navigationの自己位置同定の手順を示したものである。自己位置 同定では，教示走行によって記憶されたView と，ロボット の現在位置で取得された View を照合する事で自己位置を 同定する。ナビゲーションを開始する段階では，記憶され た全ての View と現在の View を照合し, ナビゲーションの 開始位置を同定する。その後は, ロボットの進行方向に順番 にView が移り変わるため, 図 4 に示すように現在のView である current view と，前の地点で認識された View (2nd view), 次の地点で認識されるであろう View(3rd view)の みを照合に用いれば良い。このようにする事で，位置が大 きく異なる画像との誤認識を防ぐ事が可能で，照合に要す るコストも削減する事ができる。図 4 の場合は，2nd view よりも3rd viewの方が現在位置の View との相関が高いの で，ロボットは 3rd view の位置にいると認識する。一連 の教示走行と自己位置同定の手順は，実験に㧍ける条件を 統一するため, 文献 (7) の従来手法と基本的に同様の設定と した。

〈3・3〉 View の照合 本研究の教示走行に扔いて画 像を記憶するタイミングや，自己位置同定における位置の 認識にはView の相関值を用いている。View の相関值は, 二枚の View の照合によって計算する。図 5 に提案手法に おけるView の照合方法を示す。図 5(a) が記憶された画 像，(b) が現在の画像である。この二枚の画像を分割した ブロック毎に濃度変化の傾き強度を比較し, ブロック毎の 相関の有無で投票処理を行ってView 全体の相関值を計算 する。ブロック照合投票処理 ${ }^{(11)}$ は，画像の傾斜や縮尺変 化に頑健である事が知られており，移動ロボットに搭載さ れたカメラ画像を用いるView Based Navigation におい ても，View の照合が安定する利点がある。また，ブロック 照合投票処理は，遮蔽に対しても頑健性が高く，実際のナ ビゲーションに扔ける人や物による物理的なシーンの変化 にも有効である。 4 章， 5 章の実験では，実験条件を揃え るために従来手法にもブロック照合投票処理を用いている。 ここで，二枚の画像の対応するブロックの濃度変化の傾き

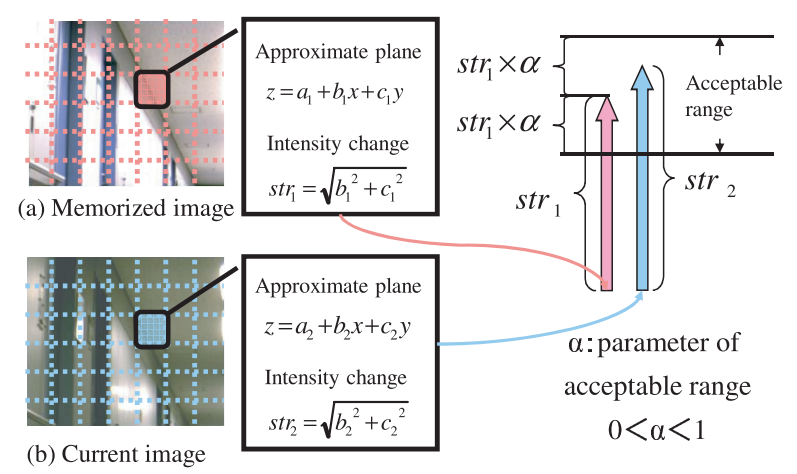

図 5 照合アルゴリズム

Fig. 5. Matching algorithm

強度 $s t r_{1}$ と $s r_{2}$ は，それぞれのブロックの輝度近似平面 の平面式 $z=a_{1}+b_{1} x+c_{1} y, z=a_{2}+b_{2} x+c_{2} y$ から (1) 式を用いて, $s t r_{1}=\sqrt{b_{1}^{2}+c_{1}^{2}}$ と $s t r_{2}=\sqrt{b_{2}^{2}+c_{2}^{2}}$ で 求まる。 $s t r_{1}$ と $s t r_{2}$ の相関は, $s t r_{1}$ にパラメー夕 $\alpha$ を掛 け合わせて設定した許容範囲に $s t r_{2}$ が納まるか否かで判断 する。このとき, st $r_{2}$ が式 (3) の条件を満たす場合, この 二つのブロックの濃度変化は類似するものとして投票する。 もし, str 2 が条件式 (4)のようにstr 1 の許容範囲の外側で あった場合は，相関が無いとして投票しない。

$$
\begin{aligned}
& \operatorname{str}_{1}(1-\alpha)<\operatorname{str}_{2}<\operatorname{str}_{1}(1+\alpha) \cdots \ldots \ldots \ldots \\
& \operatorname{str}_{2}<\operatorname{str}_{1}(1-\alpha) s \operatorname{st}_{2}>\operatorname{str}_{1}(1+\alpha) \cdots \cdots \cdots
\end{aligned}
$$

この処理を分割した全てのブロックで行い，Viewの相 関值を算出する。 $s t r_{1}$ の許容範囲の幅は $s t r_{1}$ の強度に応じ て変化する設定になっているが, これは濃度変化の傾き強 度が弱い場合はノイズによる值の摇らぎが小さく，傾き強 度が強い場合はノイズによる值の摇らぎが大きくなる事に 対応するためである。また, 教示フレーム群と実際の走行 シーンにおいて生じる位置ずれを解決するため, 教示走行 時に画像の中央部分をテンプレートとして記憶し，自己位 置同定時にこのテンプレートを左右にずらしながら照合す る事で位置ずれを補正して走行する。

\section{4. 許容範囲の評価実験}

提案手法の照明変化に対する頑健性を検証するため，実 環境においてロボットを用いた走行実験を行った。本章で は, カメラの絞りを変えて擬似的に照明変化を与え, 提案 手法の照明変化に対する許容範囲を検証する実験について 述べる。実験では，濃度值を直接的に用いる文献 (7) の従来 手法と提案手法と比較する事で, 照明変化に対する頑健性 の指標としている。従来手法は, 画像をブロックに分割し, ブロック内の輝度の平均值を用いて画像を照合する方法で, ブロック処理を用いている点で提案手法と公平な比較が可 能である。図 6 が実験において用いたロボットシステムで ある。ロボットは, VGA の CMOS イメージセンサを搭載 しており，撮像した画像はUSB を通してロボットに搭載し 


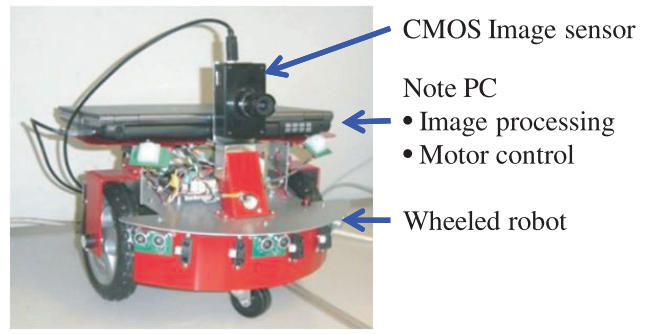

図 6 実験に用いたロボットシステム

Fig. 6. The robot system used for the experiments

てあるノート PCに転送される。ノート PCでは，画像処 理プログラムによって撮像した画像をView に変換し，こ のView を記憶，照合する事で自己位置を同定する。教示走 行では，画像を記憶した地点とロボットのエンコーダ值を 走行データとして記憶し, 自己位置同定では, 認識した自 己位置とエンコーダ值を記憶しておく。これらの実験デー 夕から，ナビゲーションの可否を検証する。また，ロボッ トの走行制御は，ノート PC からシリアルケーブルを通し て行った。このロボットシステムを用いて本研究棟廊下を $14 \mathrm{~m}$ 走行させ，照明が変化しても正しく自己位置を同定し てナビゲーションができるかを検証した。このとき，教示 走行時と自己位置同定時でカメラの絞りを変え, 撮像画像 の平均濃度值を変える事で，擬似的に照明变化を再現した。 ここでの照明変化は絞りによるものなので，画像全体に一 様に生じる。

実験では，教示走行における画像の平均濃度值を図 7 中 央のように 77 階調とし, カメラの絞りを調整して画像の 平均濃度值を徐々に变化させながら自己位置同定を行った。 その結果，記憶した全ての地点で正しく自己位置を同定し てナビゲーションできた明るさの上限と暗さの下限を調査 し，この幅を照明変化に対する許容範囲として図 7 に示す。 このとき，ブロックサイズは大きくするほど記憶量や計算 量の点で有利であるが, 解像度の低下によりステアリング 制御の分解能が下がるなどの問題がある。文献(7)において この問題に関して検討されており，VGAの画像をブロック サイズ $15 \times 15$ (pixel) で処理した View が妥当であるとさ れていた事から，実験の条件を従来手法と揃えるために提 案手法のブロックサイズも $15 \times 15 （$ pixel）と設定した。

図 7(a)，(b) は，それぞれ従来手法と提案手法の実験結 果である。図 $7(\mathrm{a})$ の従来手法では, ナビゲーション可能な 暗さの下限は濃度值 62 , 平均濃度值との差は-15 階調であ り，明るさの上限は濃度值 119 , 平均濃度值との差は+42 階調であった。したがって，上限と下限との差から，照明 変化に対する許容範囲は 57 階調であった。

これに対して, 図 7(b) の提案手法では, ナビゲーショ ン可能な暗さの下限が濃度值 41 の-36 階調，明るさの上限 が濃度值 158 の+81 階調で，照明変化に対する許容範囲は 117 階調であった。従来手法と提案手法の照明変化に対す る許容範囲を比較すると，提案手法は従来手法に対して約

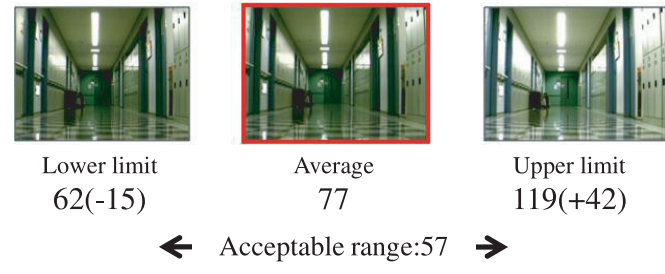

(a) An experimental result of the conventional method
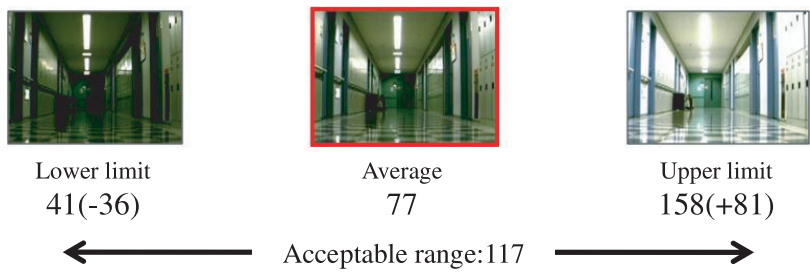

(b) An experimental result of the proposal method

図 7 照明変化に対する許容範囲の実験結果

Fig. 7. Acceptable range experimentally obtained to illumination changes

2 倍程度の許容範囲をもっている事がわかった。本実験に おける照明変化に対する許容範囲は, カメラの絞りを調整 して擬似的に照明変化を再現したため, 実環境での照明変 化に対する頑健性を直接的に示すものではないが，画像全 体で明るさが均一に変化する場合は, 提案手法は従来手法 に比べて広範囲な照明の変化に対応できる事が示唆された。

\section{5. 実環境での走行実験}

$\langle\mathbf{5} \cdot \mathbf{1}\rangle$ 蛍光灯の点灯数の変化 実際の屋内環境での 照明変化は, 太陽光や屋内照明の変化によって起こるため, 画像全体の明るさが均一に変化するとは限らない。本実験 では，実環境での照明変化として (1) 廊下の蛍光灯の点灯数 の変化, (2) 昼夜の空からの太陽光の変化について走行実験 を行った。ブロックサイズは，前章と同様に $15 \times 15($ pixel $)$ とした。図 8(a), (b) は, それぞれ教示走行時と自己位置同 定時の廊下の照明条件である。教示走行時には, 廊下に設 置されている蛍光灯の半分を点灯し, 自己位置同定時には, 廊下の全ての蛍光灯を点灯させた。図 8(c) は, 矢印の方向 にロボットが走行した廊下の $12 \mathrm{~m}$ の経路を表している。

図 9(a), (b) は, 図 8 に示した環境で得られた従来手法 (7) と提案手法のそれぞれの走行実験の結果である。同図の横 軸は走行距離， マは教示走行において画像を記憶した位置 であり，ヶ○ーは自己位置を同定した区間と位置番号を表 している。これらの位置や区間の情報は, ロボットのエン コーダから取得している。エンコーダは, 走行距離が長くな ると誤差が蓄積される問題があるが, 本実験でのエンコー ダの誤差は，検証する精度に比べて十分に小さいため，エ ンコーダの值を基準值として用いる。ナビゲーションの可 否は, 走行経路上でView を記憶したすべての地点において 正しく自己位置が同定されているか否かで判断した。教示

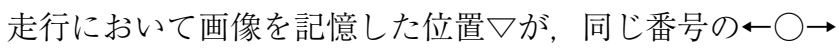
の区間の内に位置している場合，自己位置は正しく同定さ 


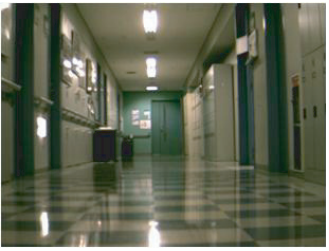

(a) The illumination condition in recording run

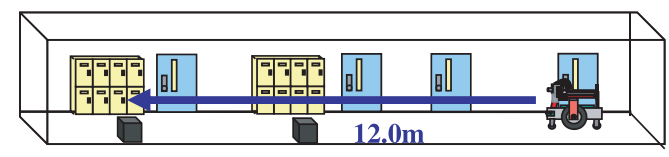

(c) Run path

図 8 照明変化の実験環境

Fig. 8. An environment used for the experiment of illumination changes

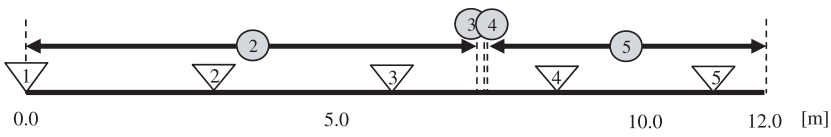

(a) An experimental result of the conventional method

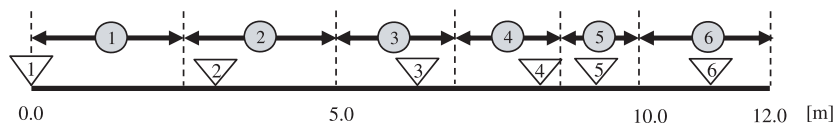

(b) An experimental result of the proposal method

No : Memorized position No. Identified position

図 9 図 8 の環境における走行実験の結果

Fig. 9. Experimental results obtained in the environment of Fig.8

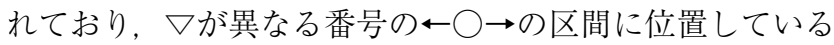
場合，自己位置は誤って同定されている。例えば，図 9(a) の従来手法では，教示走行において View が5 枚記憶され たため， 、は 1 から 5 番まである。しかし自己位置同定に おいては，最初から自己位置を 2 番と誤認識してしまい, 教示走行において記憶された 1 番の画像は認識されていな い。これは，照明の変化によって画像が正しく照合されな かった事が原因であると考えられる。後の 3 番，4番の位 置においても，自己位置を 2 番， 5 番と誤認識しており，従 来手法では蛍光灯の点灯数が変化した場合, 正しく自己位 置を同定する事は困難であった。同様の環境で 10 回の走 行実験を行ったが, 従来手法では 1 度も全ての地点で正し く自己位置を同定する事ができなかった。

一方, 図 9(b) の提案手法では, 教示走行において 6 枚の 画像が記憶され，記憶された全ての位置において，記憶画 像の番号 とと自己位置同定の番号○が対応して推移してい る事がわかる。この事から提案手法は, 蛍光灯の点灯数を 変化させた本実験において，正しく自己位置を同定できた 事が確認できる。提案手法でも同様の環境で 10 回の走行 実験を行ったが，10 回中 9 回で全ての地点で正しく自己位 置を同定する事ができた。1 回失敗したケースは, 教示に

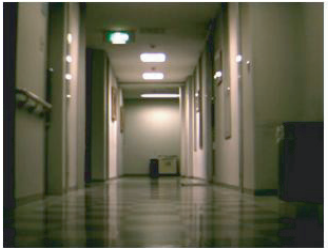

(a) The illumination condition in recording run

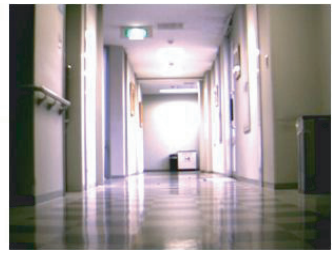

(b) The illumination condition in identification

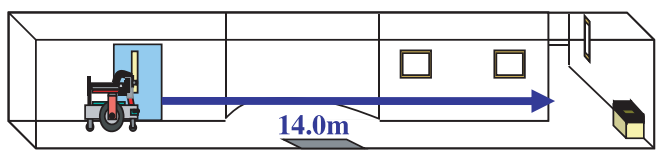

(c) Run path

図 10 空からの日照が変化する実験環境

Fig. 10. An environment used for the experiment of condition changes due to daylight from windows

おける位置と認識された位置が少しずれた場合で，記憶画 像は順番に最後まで照合されており，ナビゲーションは正 常に行われている。認識位置がずれた原因としては, 教示 走行において点灯した蛍光灯の輪郭の部分において相関值 が低下した事が考えられる。

$\langle\mathbf{5} \cdot \mathbf{2}\rangle$ 昼夜の太陽光の変化 図 10(a), (b) は, それ ぞれ教示走行時と自己位置同定時の廊下の照明条件である。 教示走行は, 夜間に廊下の蛍光灯の照明のみで行い, 自己 位置同定は，日中に廊下の蛍光灯と画像右側の空から太陽 光が差し込む状態で行った。図 10(c) の矢印は, ロボット が走行した廊下の経路を示している。走行経路は太陽光が 差し込む空を右側にして廊下の $14 \mathrm{~m}$ を直進させた。

図 11(a)，(b) は，図 10 の環境で行った従来手法と提案手 法のそれぞれの走行実験の結果である。同図の見方は，5.1 節と同様である。図 11(a)の従来手法では, 教示走行にお いてマが 1 から 8 番まで記憶された。自己位置同定におい ては, 教示走行で画像を記憶した位置と, 自己位置同定の 番号が一致しているのは 4 番のみで, 他の区間では正しく 自己位置を同定する事はできなかった。これも 5.1 節と同 様に, 照明の変化によって画像が正しく照合されなかった 事が原因である。従来手法では，昼夜で空からの太陽光が 変化した場合，正しく自己位置を同定する事が困難である 事がわかった。同様の環境で従来手法を用いて行った 10 回 の実験では， 1 度も全ての地点で正しく自己位置を同定す る事ができなかった。

一方，図 11(b) の提案手法では，教示走行において 6 枚 の画像が記憶され，記憶されたすべての位置において，記 憶画像の番号 $\nabla$ と自己位置同定の番号○が対応して推移し ている。提案手法は, 昼夜で空から差し込む太陽光が変化 する本実験においても, View を記憶した全ての地点で正し く自己位置を同定する事ができた。同様の環境で提案手法 を用いて行った 10 回実験においては, 10 回中 7 回で全て の地点で正しく自己位置を同定する事ができた。 3 回失敗 したケースがあるが，これも 5.1 節と同様に教示における 
位置と認識された位置が少しずれた場合で，ナビゲーショ ンは正常に行われている。位置ずれの原因としては，日中 の太陽光によって画像中に白とびが発生しており, これに よってエッジが欠損し，画像の相関值を低下させた事が考 えられる。

$\langle\mathbf{5} \cdot 3\rangle$ 考 察 実環境で考えられる照明変化につい て従来手法と提案手法を比較して，照明変化に対する頑健 性を実験的に検証してきた。その結果，提案手法は従来手 法に対して，照明変化における頑健性が高い事が示唆され た。これは，照明が変化した場合でも提案手法の方が安定 して画像を照合する事ができたためである。ここでは，5.1 節の蛍光灯の変化の実験に着目して, 提案手法の照明変化 に対する頑健性がなぜ従来手法に比べて高いのか考察する。

図 12 は，実験において異なる照明条件下で撮像された廊 下の画像である。図 12(a) が教示走行，図 12(b) が自己位 置同定の画像で蛍光灯の点灯数が変化している。まず，画 像中の $\mathrm{A}$ と $\mathrm{A}^{\prime}$ の区間に注目すると，蛍光灯の $\mathrm{ON}, \mathrm{OFF}$ によってほぼ均一に画像の明るさが変化している。図 12 の

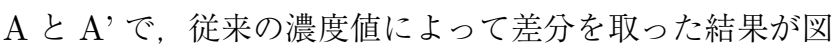
13(a)であり，提案手法の濃度変化を用いて変化量の差分を 取った結果が図 13(b) である。図 13(a), (b) の横軸は画像 の水平方向のブロック数，縦軸はそれぞれ濃度值と濃度変 化值である。グラフの斜線部の面積は照明変化前の図 $12(\mathrm{a})$ と照明変化後の (b) における差分を表している。図 13(a)

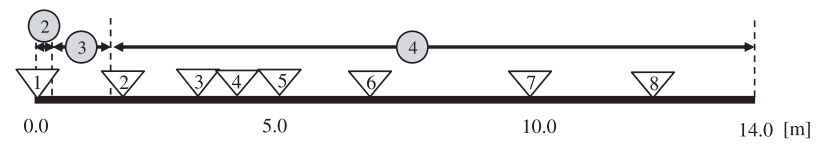

(a) An experimental result of the conventional method

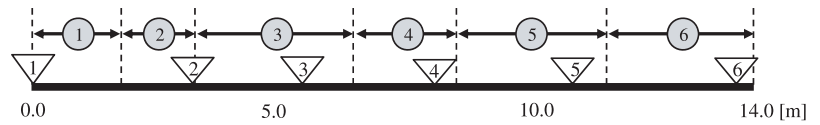

(b) An experimental result of the proposal method

NV: Memorized position (No. : Identified position

図 11 図 10 の環境における走行実験の結果

Fig. 11. Experimental results obtained in the environment of Fig.10

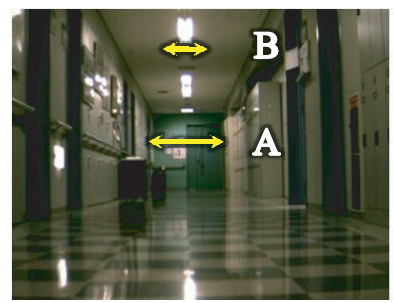

(a) Captured image in recording run

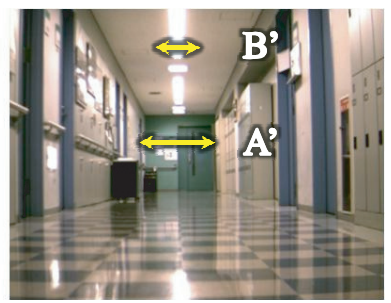

(b) Captured image in identification
図 12 異なる照明条件での撮像画像

Fig. 12. Captured images in different illumination conditions
の従来手法がグラフ全体で照明変化の影響を受けているの に比べ，図 13(b) の提案手法では，部分的に変化した箇所 はあるが，その他の箇所で大きな変化は見られない。これ は，従来手法が濃度值そのものをべースとしていたのに対 して，本手法では輪郭をべースとして画像を照合するため, 画像全体で均一な照明の変化に影響され難くなった効果で ある。

画像中の B と B' の区間に注目すると, 蛍光灯の $\mathrm{ON}$, OFF によって蛍光灯の部分だけ大きく画像の明るさが変化 している。Bと B'の差分をグラフに表したものが図 14 で ある。図 14(a) は従来の濃度值による結果, 図 14(b) が提 案手法の濃度変化による結果である。グラフの斜線部に注 目すると図 14(a) の従来手法がグラフ全体で照明変化の影 響を受けているのに比べ, 図 14(b) の提案手法では, グラ フの変化を蛍光灯の輪郭部分のみに抑制できている事がわ かる。これは, 部分的に照明が変化した例とも言える。輪郭 ベースの本手法では，変化した領域の淵の部分で照合が困 難になるが，変化した領域の内部で照合できるために相関 值の低下を抑えることができる。また，ノイズに影響され やすい輪郭の情報を用いているにも関わらず, 図 13(b), 図 14(b) のどちらのグラフにおいても，ノイズによる突発的 なエッジの検出は少なく, 輝度近似平面のエッジをブロック 単位で平均化する作用が有効に働いている事が確認できる。

今回の実験で使用したノート PC (CPU:1.8GHz, Memory:1GByte, OS:WindowsXP) における本手法の処理時 間は，教示走行時の画像の変換と保存に平均 $19 \mathrm{~ms}$ ，位置同 定時の画像の変換と照合に平均 $42 \mathrm{~ms}$ である。これは，口

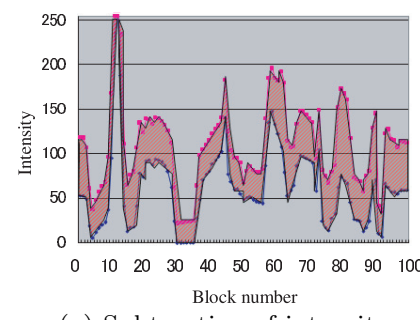

(a) Subtraction of intensity

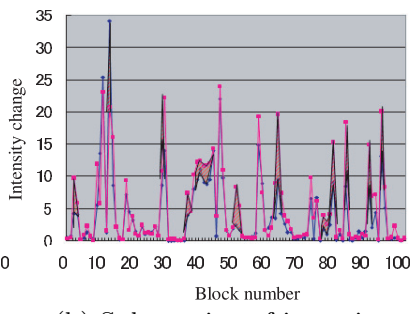

(b) Subtraction of intensity change
図 13 図 12 の A， A'における差分

Fig. 13. Subtraction of position A and A' in Fig.12

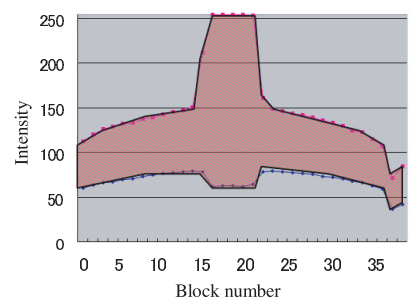

(a) Subtraction of intensity

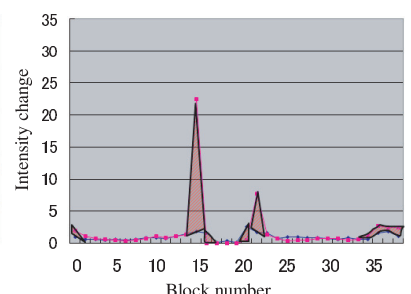
change (b) Subtraction of intensity

図 14 図 12 のB，B'における差分

Fig. 14. Subtraction of position B and B' in Fig.12 
ボットが人の歩行速度程度で廊下を走行することに問題の 無いレベルである。すなわち，View の生成に濃度変化の 情報を用いる事により，濃度值を直接的に用いたこれまで の手法の課題を改善できる事が明らかになった。特に, こ こで用いた輝度近似平面法は濃度変化を検出する一手法で あるが，ロボットに搭載する上では簡便な方法として有効 である事が示された。

\section{6. おわりに}

本稿では, LCD パネルの輝度の不均一を検出する方法と して開発した輝度近似平面を応用し，画像中のノイズの影 響を除去しながら環境の照明変化を許容した画像の比較方 法を提案した。さらに，輝度近似平面の耐ノイズ性と照明 変化に対する頑健性をView Based Navigationに適用し てその効果を検証してきた。

カメラの絞りによって再現した擬似的な照明変化の実験 では，照明変化に対する許容範囲を検証し，本手法が従来 の濃度值を直接的に用いた手法に比べて 2 倍程度の一様な 画像の明るさの変化に対応できる事が示された。また，実 際に屋内の太陽光や蛍光灯の照明条件が変化する環境で移 動ロボットを用いた走行実験を行い，本手法は従来手法に 比べて実環境で生じる照明変化に対しても頑健性がある事 が示された。この結果から, 輝度近似平面のView Based Navigationへの適用は, 環境の一様な照明の変化に対して 有効であり，実環境での照明の変化に対しても限定的であ りながら有効性が示された。しかし，実環境における実験 では, いくつか失敗するケースも確認されている。これは, 本手法が一様な照明変化には高い頑健性を有するが, 部分 的な照明変化には多少の影響を受ける事が要因であると考 えられる。特に, 画像の白とびや黒落ち, 及び部分的な照 明の変化が画像内に占める割合が大きい場合に照合が困難 になると考えられる。これらの画像の変化における課題は, カメラのオートアイリスの使用や，撮像画像のダイナミッ クレンジ，コントラスト改善に関する研究 ${ }^{(12)}$ の適用によっ て解決していきたい。

\section{謝 辞}

本研究の一部は, 文部科学省私立大学学術研究高度化推 進事業「私立大学社会連携研究推進事業」(平成 18 年度 平成 22 年度) : 研究課題「測位/光神経複合センサノード によるユビキタス・モニタリング・ネットワークの開発と その産業応用への展開」の一環として実施したものである。 記して，厚く御礼申し上げます。

(平成 21 年 1 月 26 日受付, 平成 21 年 6 月 15 日再受付)

\section{文献}

(1) R.L. Lillestrand: "Techniques for change detection", IEEE Trans. Computer, Vol.C-21, No.7, pp.654-659 (1972)

(2) Y. Satoh, S. Kaneko, Y. Niwa, and K. Yamamoto: "Robust Object Detection by Radial Reach Filter", IEICE, Vol.J86D2, No.5, pp.616-624 (2003) (in Japanese)
佐藤雄隆 - 金子俊一 - 丹羽義典 - 山本和彦：「Radial Reach Filter(RRF)によるロバストな物体検出」, 信学論, 86-D2, 5, pp.616624(2003)

(3) I. Murase, S. Kaneko, and S. Igarashi: "Robust Matching by Increment Sign Correlation", IEICE, Vol.83-D2, No.5, pp.1323-1331 (2000) (in Japanese)

村瀬一郎・金子俊一・五十嵐悟:「増分符号相関によるロバス卜画像 照合」, 信学論, 83-D2, 5, pp.1323-1331 (2000)

(4) Y. Choi, K. Ueno, M. Kamiuchi, T. Iyota, K. Watanabe, and Y. Kubota: "Detection of uneven brightness for LCD panel using approximate planes of brightness in a CCD image", SICE, Vol.41, No.1, pp.1-7 (2005) (in Japanese)

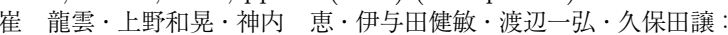
「LCD パネルにおける画像の輝度近似平面を用いた色表示の不均一 の検出」, 計測自動制御学会論文集, 41, 1, pp.1-7 (2005)

(5) Y.Hagiwara, Y.Choi, T.Iyota, Y.Kubota, and K.Watanabe: Practical Application of the Brightness Approximation Plane Method with a Simple Parameter, Proc. of Int. Conf. on ICCAS '07, p.105 (2007)

(6) I. Horswill. Polly: "A Vision-Based Artificial Agent", Proc. of Int. Conf. on AAAI '93, pp.824-829 (1993)

(7) Y. Matsumoto, M. Inaba, and H. Inoue: "View-Based Approach to Robot Navigation", JRSJ, Vol.20, No.5, pp.44-52 (2002) (in Japanese)

松本吉央・稲葉雅幸・井上博允：「ビューベーストアプローチに基 づく移動ロボットナビゲーション」, 日本ロボット学会誌, 20, 5, pp.506-514 (2002)

(8) H. Isawa, N. Aihara, N. Yokoya, and H. Takemura: "MemoryBased Self-Localization Using Omnidirectional Images", IE$I C E$, Vol.J84-D2, No.2, pp.310-320 (2001) (in Japanese) 岩佐英彦・栗飯原述宏・横矢直和・竹村治雄：「全方位画像を用いた 記憶に基づく位置推定」, 信学論, 80-D2, 2, pp.310-320（2001）

(9) Y. Takeuchi and M. Hebert: "Evaluation of ImageBased Landmark Recognition Techniques", CMU-RI-TR-9820 (1998)

(10) J. Miura, H. Morita, M. Hild, and Y.Shirai: "A View-Based Outdoor Localization Using Object and Location Recognition Based on Support Vector Learning", JRSJ, Vol.25, No.5, pp.792-798 (2007) (in Japanese)

三浦 純・森田英夫・ヒルドミヒャエル・白井良明：「SVMによる 物体と位置の視覚学習に基づく屋外移動ロボットの位置推定」, 日 本ロボット学会誌, 25, 5, pp.792-798 (2007)

(11) F. Saitoh: "Robust Image Matching for Occlusion Using Vote by Block Matching", IEICE, Vol.84-D2, No.10, pp.2270-2279 (2001) (in Japanese)

斎藤文彦:「ブロック照合投票処理を用いた遮へいに強い画像マッチ ング」, 信学論, 84-D2, 10, pp.2270-2279（2001）

(12) F. Saitoh : "Image Contrast Improvement Based on Differential Gray-levels Histogram", IEEJ Trans. EIS, Vol.126, No.2, pp.228-236 (2006) (in Japanese)

斉藤文彦:「濃度勾配ヒストグラムによる画像のコントラスト改善」, 電学論, 126, 2, pp.228-236 (2006)

萩 原 良 信 (非会員) 2003 年創価大学工学部情報システム

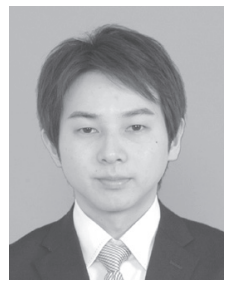
学科卒業。2005 年同大学院工学研究科情報シス テム学専攻修士課程修了。現在, 同大学院工学研 究科情報システム学専攻博士課程在学中。ロボッ トビジョン，画像処理の研究に従事。 
清 水 幸 夫（非会員） 2006 年創価大学工学部情報システム 学科卒業。2008 年同大学院工学研究科情報シス テム学専攻修士課程修了。同年パナソニック半導 体テクノ(株)に入社。在学中は主にロボットビ ジョンの研究に従事。

崔

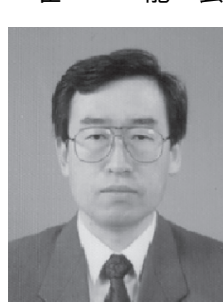

久保田

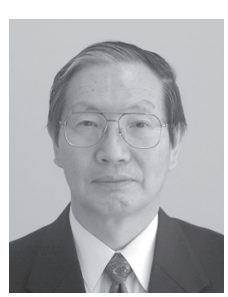

渡 辺 - 弘（正員） 1976 慶應義塾大学工学部電気工学科卒

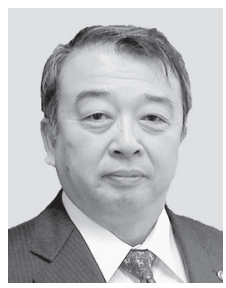

業。1981 同大学院工学研究科電気工学専攻博士 課程修了。同年より防衛大学校電気工学教室助手, 講師, 助教授を経て, 1991 年創価大学工学部助 教授。現在, 創価大学工学部情報システム工学科, 教授, 副学長補, 工学部長。工学研究科長, 社会 連携・知的財産戦略本部長。レーザの光情報装置 への応用, 光ファイバセンサ, 自律移動ロボット の自己位置認識システム, ユビキタス空間の開発の研究に従事。計測 自動制御学会, レーザ学会, 日本ロボット学会, 応用物理学会等の会 員。(工学博士) 